\title{
TESTING OF THE FLAME SPREAD LINEAR SPEED ON FOODSTUFFS AND AGRICULTURE DUST LAYERS
}

The paper deals with results of linear speed tests on foodstuffs and agriculture dust layers. The experiments were performed with different samples, focusing on flame spread on the dusts layers occurred in agriculture and food industry.

\section{Introduction}

Nowadays there is an absence of experimental knowledge in the field of organic dust combustion and this status requires to quantify in a detailed way particular conditions of the initiation as well as propagation of the burning process of these materials.

This paper aims to contribute to the extension of the burning process measurement problems in the case of sedentary organic dusts. Research up to now has dealt with dust problems on a lignocellulose materials basis. Subject research focused on the linear speed monitoring of the flame spread on sedentary dusts layers occurred in agriculture and food industry, depending on the conditions as thickness, sedentary layer moisture and area tilt, where the dust is sedentary.

Test results should contribute to:

- the development of such testing methods, which monitor sedentary dusts burning propagation,

- the knowledge acquisition, dealing with the linear speed of sedentary organic dusts burning depending on exterior conditions

\section{Applied testing method}

The measuring method is based on dust property to ignite after the initiation of a sufficiently intensive source and on the property of the flame transfer to further layers of sedentary dust. To make the measurement easy and fast, the whole measurement process is carried out in the oxygen atmosphere. Measured values are for this reason relative and they are not identical with the flame-spread speed in the air. [2] Burning process in practice in the absolute oxygen atmosphere may occur in technologies having their own oxygen distributions or in technologies working with pressure vessels, containing pure oxygen. During the measurement when the flame is transmitted from the sample surface to the indicated distance time is measured and from these values the flame-spread speed is calculated. The measurement is performed at the RO test apparatus (test of the oxidation speed). [1,2]

\section{RO apparatus description}

The main component part of the RO apparatus is a tube made of chemical glass, with the inside diameter of $22 \mathrm{~mm}$ and a length of $200 \mathrm{~mm}$, fastened to a metal holder situated in the apparatus upper board. The tube is connected to the steel pressure vessel with oxygen by the air pressure reducing valve and the rub hose strengthened by textile fibre. The quantity of incoming oxygen for the measurement is set by a regulator of the gas flow. A sample of measured dust is inserted into the open tube ending formed in the shape of standard bar form. A metal mat is indicated by notches of 100-mm distance between each other, limiting intended length of the formation supposed for measurement. The forms create formations of the height of $3.5 \mathrm{~mm}$ and $7 \mathrm{~mm}$, length of $120 \mathrm{~mm}$, the base width is $10 \mathrm{~mm}$. The burning zone width is $12.2 \mathrm{~mm}$ at a $3 \mathrm{~mm}$-dust layer thickness, as for 5-mm dust layer thickness there is $15.7 \mathrm{~mm}$ and for a dust layer of $13.1 \mathrm{~mm}$ thickness it is $7 \mathrm{~mm}$. For the period measurement necessary for the flame spread along the length of the formation, the hand stopwatch is utilized. Sample ignition is performed at the operating path with the length of $15 \mathrm{~mm}$ by standard safety matches (STN EN 1783:1997: SAF).

\section{Apparatus parametres:}

Pressure of $\mathrm{O}_{2} 20-50 \mathrm{MPa}$, pressure in the testing tube is identical with the surrounding atmospheric pressure. The extent of volume flow is $0-11 \cdot \mathrm{min}^{-1} \cdot[1,2,4]$

\section{Operating procedure}

Before the beginning of measurement the oxygen pressure vessel is opened and the constant volume oxygen overflow through the tube is set by air pressure reducing valve at $0.1751 . \mathrm{min}^{-1}$. The measured sample is prepared in the shape of formation, to a metallic pad by a dust tumble from the bar. The formation is prepared in such a way that the dust is given into the bar and the redundant dust sample is removed by a metallic plate in the angle of $45^{\circ}$.

\footnotetext{
* Ján Slosiarik

Technical University in Zvolen, Faculty of Wood Sciences and Technology, Department of Fire Protection, Masaryka 24, SK-960 53 Zvolen, E-mail: slos@vsld.tuzvo.sk
} 


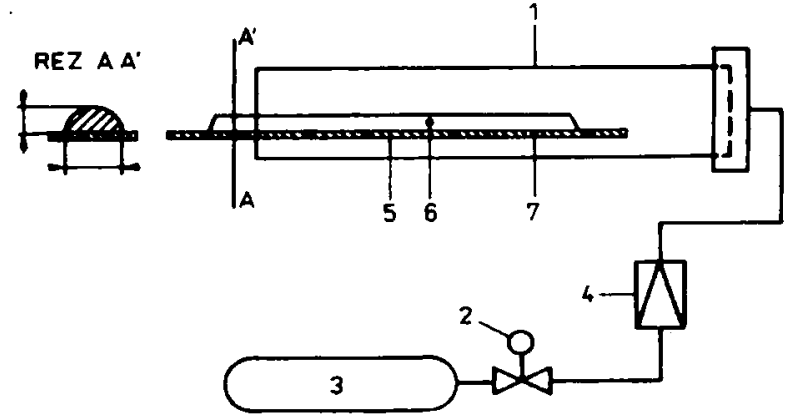

Fig. 1 Scheme of the equipment for oxidation speed determination ( $R O$ test)

(1 - combustion tube, 2 - air pressure reducing valve, 3 - pressure vessel for oxygen, 4 - flow measurement device, 5 - metallic pad, 6 - dust sample, 7 - notches)

Dust compression does not appear in this way and after the dump to the metallic pad the formation with smooth surface is created. The total length of formation is $120 \mathrm{~mm}$. The measured sample is located at the metallic pad in such a way that one side of the formation would be exactly at one scratch, another scratch then exceeds the formation by $15 \mathrm{~mm}$. An exceeding part of the formation serves for the sample ignition. The stop-watch is switched on when the flame is going to spread after the ignition, to the level of the chemical glass edge. Necessary time for the flame spread on the sample surface is measured by the stop-watch, in the oxygen countercurrent alongside the formation length of $100 \mathrm{~mm}[1,2,3]$ The test samples were tested at the horizontal position and at $35^{\circ}$ inclination as well.

\section{Measurement results processing and tasks evaluation}

The final measurement value is an average time interval given in seconds, during which the flame is spread on the dust layers, alongside the length of $100 \mathrm{~mm}$. Measurements for the given dust sample and given oxygen overflow in the combustion tube are performed five times and from the obtained measurements the average value of linear spread flame speed is calculated for the sample of flammable dust layer in the oxygen atmosphere according to the reference (2): $[1,2,3]$

$$
W_{0}=\frac{l}{\tau}\left[\mathrm{m} \cdot \mathrm{s}^{-1}\right]
$$

$W_{0}$ - spread flame speed (oxidation speed) on the dust layer

$l$ - dust layer length in the defined intersection [m]

$\tau$ - time of the flame transfer alongside the layer length 1 [s]

\section{Result evaluation}

Nowadays there is no hazard classification system for industrial dusts, besides coal dusts, where the methodology of 3 danger classes has been accepted. For the dust classification previous system has been applied as for [3,4], extended by further class IV. according to Table. 1 .
Classes of the flame spread danger on the surface of Tab. 1 sedentary industrial dusts, based on the oxidation speed test

\begin{tabular}{|c|c|c|}
\hline $\begin{array}{c}\text { Danger } \\
\text { Class }\end{array}$ & $\begin{array}{c}\text { Dust Fire } \\
\text { Characteristics }\end{array}$ & $\begin{array}{c}\text { Oxidation } \\
\text { Speed (RO) [s] }\end{array}$ \\
\hline I. & Dust spreads the fire very well & RO $\leq 10 \mathrm{~s}$ \\
\hline II. & Dust spreads the fire & $10 \mathrm{~s}<\mathrm{RO} \leq 20 \mathrm{~s}$ \\
\hline III. & Dust spreads with difficulties & $20 \mathrm{~s}<\mathrm{RO}$ \\
\hline IV. & Dust does not spread the fire & $\mathrm{RO}=0 \mathrm{~s}$ \\
\hline
\end{tabular}

Indication of moisture influence on linear flame spread speed in the atmosphere of pure oxygen, taking into consideration the thickness of sedentary dust and cocoa dust sample tilt, dried milk, foodstuff, flour and wheat grouts.

Experimental tests have been carried out by the method known as "RO test" for the flame burning propagation in the atmosphere of pure oxygen at the dynamic counter current flow of $0.1751 . \mathrm{min}^{-1}$, which represented the speed of air circulation in the tube of $0.85 \mathrm{~cm} \cdot \mathrm{s}^{-1}$. For an experiment the following samples were utilized:

- cocoa of $0 \%$ moisture and technological moisture of $8 \%$,

- dried milk of $0 \%$ moisture and technological moisture of $4 \%$,

- foodstuff compound of $0 \%$ moisture and technological moisture of $10 \%$,

- flour of $0 \%$ moisture and technological moisture of $14 \%$ and

- wheat grouts of $0 \%$ moisture and technological moisture of $16 \%$.

Three thicknesses of sedentary cocoa dust, dried milk, foodstuff compound, flour and wheat grouts were observed $(3 \mathrm{~mm}$, $5 \mathrm{~mm}, 7 \mathrm{~mm}$ ).

Besides the measurement of particular dust samples at different moistures and layer heights in the horizontal position, measurement was carried out also at the $35^{\circ}$ slant. The tube with a sample was sloping in such a way that its opening for dust samples was in the downward direction. Tube slant of $35^{\circ}$ ("shoot angle") was indicated in such a way that the position during which the sample stayed in the tube was found out.

The complete comparison of the horizontal position of $35^{\circ}$. sample slant (at the technological moisture of $0 \%$ moisture) is given in Tables 2 and 3.

\section{Conclusion}

The measured data for researched samples confirmed theoretical assumptions about the influence of outside conditions, i.e. dust moisture, layer height, and dust sample slant on the result values. Identified dependencies:

Dust moisture - the measured samples were of 4 to $16 \%$ of technological moisture. The results measured at the technological moisture were compared with the results measured at $0 \%$ moisture. With the increasing moisture a burning time prolongation for all samples was noticed. The flour sample proved the value, which 
Comparison of the horizontal position of $35 \%$ sample slant at the technological moisture

\begin{tabular}{|c|c|c|c|c|c|c|c|}
\hline \multirow{3}{*}{$\begin{array}{c}\text { Sample } \\
\text { name }\end{array}$} & \multicolumn{6}{|c|}{ Thickness of sedentary dust } & \multirow{3}{*}{$\begin{array}{c}\text { Moisture } \\
{[\%]}\end{array}$} \\
\hline & \multicolumn{2}{|c|}{$3 \mathrm{~mm}$} & \multicolumn{2}{|c|}{$5 \mathrm{~mm}$} & \multicolumn{2}{|c|}{$7 \mathrm{~mm}$} & \\
\hline & 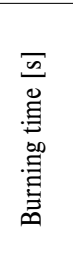 & 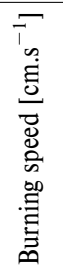 & 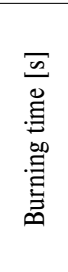 & 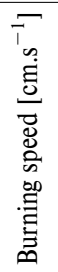 & 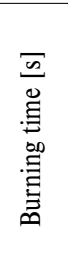 & 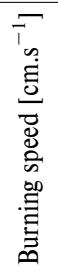 & \\
\hline \multicolumn{8}{|c|}{ Sample in the horizontal position } \\
\hline cocoa & 4.68 & 2.15 & 3.26 & 3.10 & 2.37 & 4.30 & $8 \%$ \\
\hline dried milk & 7.68 & 1.30 & 6.97 & 1.44 & 4.33 & 2.31 & $4 \%$ \\
\hline foodstuff & 9.56 & 1.09 & 8.50 & 1.18 & 2.77 & 3.67 & $10 \%$ \\
\hline flour & 14.69 & 0.68 & 13.08 & 0.76 & 10.64 & 0.94 & $14 \%$ \\
\hline wheat grouts & 8.93 & 1.12 & 8.28 & 1.21 & 5.28 & 1.92 & $16 \%$ \\
\hline \multicolumn{8}{|c|}{ Sample of $35^{\circ}$ slant } \\
\hline cocoa & 4.81 & 2.08 & 4.97 & 2.02 & 3.65 & 2.76 & $8 \%$ \\
\hline dried milk & 7.43 & 1.35 & 7.46 & 1.34 & 4.28 & 2.35 & $4 \%$ \\
\hline foodstuff & 12.18 & 0.84 & 6.86 & 1.48 & 3.47 & 2.89 & $10 \%$ \\
\hline flour & 17.25 & 0.58 & 16.15 & 0.62 & 10.38 & 0.97 & $14 \%$ \\
\hline wheat grouts & 10.87 & 0.92 & 10.19 & 0.98 & 6.64 & 1.51 & $16 \%$ \\
\hline
\end{tabular}

Comment: All figures are given in the arithmetic mean

ranked it to the lower class of danger (from the first danger class to the second danger class)

Layer thickness - the measurements were performed for the layers thicknesses of $3 \mathrm{~mm}, 5 \mathrm{~mm}$ and $7 \mathrm{~mm}$. The layer thickness increase represented the oxidation speed increase, with one exception. Anomaly appeared only in the sample of cocoa dust of $0 \%$ moisture, where the oxidation speed decrease appeared at the $5 \mathrm{~mm}$ layer height compared with the oxidation speed for the dust sample of $3 \mathrm{~mm}$ height. This anomaly could be caused, for example, by a sample contamination, etc. (samples were checked just only by a riddle analysis, not by a chemical one).
Tab. 2 Comparison of the horizontal position of $35^{\circ}$ sample slant at $0 \%$ moisture

\begin{tabular}{|c|c|c|c|c|c|c|c|}
\hline \multirow{3}{*}{$\begin{array}{l}\text { Sample } \\
\text { name }\end{array}$} & \multicolumn{6}{|c|}{ Thickness of sedentary dust } & \multirow{3}{*}{$\begin{array}{c}\text { Moisture } \\
{[\%]}\end{array}$} \\
\hline & \multicolumn{2}{|c|}{$3 \mathrm{~mm}$} & \multicolumn{2}{|c|}{$5 \mathrm{~mm}$} & \multicolumn{2}{|c|}{$7 \mathrm{~mm}$} & \\
\hline & 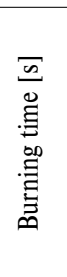 & 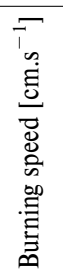 & 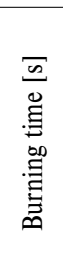 & 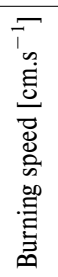 &  & 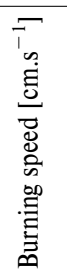 & \\
\hline \multicolumn{8}{|c|}{ Sample in the horizontal position } \\
\hline cocoa & 3.06 & 3.34 & 3.19 & 3.16 & 1.83 & 5.72 & $0 \%$ \\
\hline dried milk & 3.97 & 2.53 & 3.83 & 2.63 & 2.29 & 4.41 & $0 \%$ \\
\hline foodstuff & 4.59 & 2.18 & 2.70 & 3.81 & 1.66 & 6.10 & $0 \%$ \\
\hline flour & 4.34 & 2.31 & 3.87 & 2.59 & 2.88 & 3.53 & $0 \%$ \\
\hline wheat grouts & 2.74 & 3.65 & 2.59 & 3.86 & 1.53 & 6.67 & $0 \%$ \\
\hline \multicolumn{8}{|c|}{ Sample of $35^{\circ}$ slant } \\
\hline cocoa & 4.08 & 2.46 & 3.45 & 2.91 & 2.73 & 3.67 & $0 \%$ \\
\hline dried milk & 4.11 & 2.43 & 5.00 & 2.00 & 2.10 & 4.78 & $0 \%$ \\
\hline foodstuff & 5.26 & 1.91 & 3.77 & 2.71 & 1.78 & 5.65 & $0 \%$ \\
\hline flour & 4.89 & 2.05 & 4.08 & 2.45 & 3.21 & 3.12 & $0 \%$ \\
\hline wheat grouts & 3.01 & 3.33 & 2.77 & 3.62 & 1.45 & 6.95 & $0 \%$ \\
\hline
\end{tabular}

Comment: All figures are given in the arithmetic mean

Sample slant - the measurement was performed at the horizontal position and at a $35^{\circ}$ slant. From the measured values we can assume that during the measurements there was not always a chimney effect phenomenon, on the contrary, oxidation speed was sometimes decreased probably by bad combustion products. The inlet hose for oxygen was integrated at the upper ending of the tube and because of the fact that the combustions are moving in upward direction, deceleration of the oxygen feeding to the burning zone appeared. Generally the influence of the layer tilt on the oxidation speed was confirmed $[5,6]$.

\section{References}

[1] DAMEC, J., CHOLEVA, L.: Laboratory practice of the counterexplosion of technological processes prevention, IX. správa FMV, Praha VŠB 1980, p. 71

[2] DAMEC, J., FONIOK, R., HANUŠ, A.: Counterexplosion prevention, Návody na cvičení, Vysoká škola báňská v Ostravě, Ostrava 1993, p. 7-10. ISBN 80-7078-191-2

[3] DUNAJSKÝ, M.: Linear speed of the flame spread on sedentary wood dusts, Diploma thesis, TU Zvolen, 2003, p. 83

[4] SLOSIARIK, J.: Burning of sedentary flammable dust on the basis of lignocellulose materials, Dizertačná práca, TU Zvolen, Zvolen 2002, p. 103

[5] ŠAŠKOVÁ, V.: Linear speed of the flame spread on the sedentary organic dusts layer, In: Diploma thesis, TU Zvolen, 2004, pp. 47-60

[6] MRAČKOVÁ, E.: Monitoring of wheat dusts dimensions by laser analyser due to the explosion, In: Zborník referátov $\mathrm{z}$ internetového diskusného fóra. Fórum mladých odborníkov požiarnej ochrany, 3. medzinárodný odborný seminár, KPO, TU Zvolen 2003, pp. 58-64, ISBN 80-228-1246-3 